\title{
The Effectiveness of
}

\section{Unconventional Monetary Policy in Japan*}

\author{
Heather Montgomery** \\ International Christian University, Tokyo \\ The Carolina Asia Center, University of North Carolina, Chapel Hill \\ Ulrich Volz \\ Department of Economics, SOAS University of London, London \\ German Development Institute, Bonn
}

Since the global financial crisis of 2007-2008, central bankers around the world have been forced to abandon conventional monetary policy tools in favor of unconventional policies such as quantitative easing, forward guidance, and even lowering the interest rate paid on bank reserves into negative territory. Japan, which faced a crisis in its banking sector and came up against the theoretical zero lower bound on interest rates nearly a decade earlier, was a pioneer in the use of many of these unconventional policy tools. This article analyzes the effectiveness of Japan's bold experiment with unconventional monetary policy. Using a panel of bi-annual bank data covering the full universe of Japanese commercial banks over a fifteen-year period, this study analyzes the effectiveness of quantitative easing policy on the bank lending channel of monetary policy transmission. Our findings suggest that Japan's unconventional monetary policy worked: there is a bank lending channel of monetary policy transmission in Japan. These results are robust to the inclusion of time fixed effects and generalized method of moments analysis.

JEL Classification: G21

Keywords: Japanese banks, unconventional monetary policy, quantitative easing, bank lending channel

*This article was presented in a session on "The Japanese Economy in the Age of Uncertainty" at the ASSA meetings in Atlanta, GA, January 4-6, 2019. The authors thank the organizers, other session participants and members of the audience for helpful comments.

**Corresponding author. Email: montgomery@icu.ac.jp 


\section{Introduction}

Since the global financial crisis of 2007-2008, central bankers around the world have been forced to abandon conventional monetary policy tools in favor of unconventional policies such as quantitative easing, forward guidance, and even lowering the interest rate paid on bank reserves into negative territory. In particular, facing the zero-lower-bound on interest rates, central bankers in the United States and Europe have shifted from their usual instrument of monetary policy-a targeted uncollateralized interest rate paid on overnight interbank loans-to targeting a certain level of bank reserves.

Japan was a pioneer of much of this unconventional monetary policy. The Bank of Japan (BoJ) first embarked on "forward guidance" (before the term was commonly used) in February of 1999 with its socalled "zero-interest rate policy" (ZIRP), by which BoJ Governor Hayami committed to keep the uncollateralized overnight interbank rate, the call rate, at zero "until deflationary conditions subside." The target call rate was raised to 25 basis points in August of 2000, but in retrospect, that rate raise seemed premature, and it was lowered again, this time to 15 basis points, in February 2001. With the economy still not performing at potential and mired in deflation, at its March 2001 meeting the BoJ shifted its monetary policy instrument from the call rate to the amount of bank reserves held on deposit at the BoJ.

Japan's bold experiment in targeting bank reserves was the world's first policy of quantitative easing (QE). Despite much controversy and debate, even among the monetary policy board members of the BoJ itself, this first round of quantitative easing, now referred to as "OE1," remained in effect for nearly six years. Over that period, the targeted balance of the BoJ's current account was raised several times. When the policy was first announced in March 2001, reserves were targeted at 5 trillion yen. That was raised to 6 trillion yen in August 2001 and then to a range between 10-15 trillion in December of the same year. When Hayami was succeeded by Governor Fukui in 2003, QE1 was expanded further to reach a target of 30-35 trillion by January 2004. Finally, on March 9, 2006, the BoJ lifted the quantitative easing policy by a 7-1 vote, 
citing that the three conditions for lifting QE, set out at the January 2004 monetary policy meeting, had been met. The BoJ's monetary policy instrument was switched from the BoJ current account balance back to the conventional instrument of the uncollateralized overnight call rate, although to assuage critics in the Ministry of Finance and Cabinet Office, the BoJ pledged that the targeted call rate would remain effectively at zero for some time: ZIRP would remain in place. Three months later, in July 2006, the BoJ made the historic decision to lift ZIRP and target a 25 basis point call rate. Interest rates in Japan had finally been normalized after more than six years of experimental policy.

At the end of Governor Fukui's term in March, Masaaki Shirakawa took over at the helm of the BoJ. He was soon facing the global financial crisis, or the "Lehman Shock" as it is sometimes referred to in Japan. By December 2008, policy rates were nearly at zero in the United States. The BoJ lowered the target call rate from 30 to 10 basis points and announced an increase in outright purchases of Japanese Government Bonds (JGBs) and some less conventional assets such as commercial paper. However, Governor Shirakawa insisted that this was not a return to QE. QE returned, however, in 2013, under Shirakawa's successor, Kuroda, and was promoted as the first of three "arrows" in Prime Minister Abe's economic plan, "Abenomics," which he placed at the center of his political agenda.

In April 2013, Governor Kuroda announced Qualitative and Quantitative Easing, or QQE. This was a pledge to end the "incremental" approach of the BoJ (presumably a dig at Shirakawa) by doubling the monetary base within one year and raising the average maturity of JGBS held by the BoJ. This was forecast to increase the size of the BoJ's balance sheet by about $1 \%$ of GDP each month, double the rate that had been set by the Federal Reserve Board of Governors (the Fed) under its program of "Large Scale Asset Purchases" (Fed Chair Ben Bernanke was, like Shirakawa, insistent that his policy was not QE). At the time of this writing, QQE remains in place, more than five years after it was implemented. 
What is the path of monetary policy transmission in the case of unconventional policies such as QE and QQE? One way QE is supposed to work is through the bank lending channel of monetary policy transmission. The central bank creates new money-usually electronically-and uses it to purchase large amounts of assets from commercial bank. This makes the commercial banks more liquid, which should lead to lower interest rates on loans and stimulate borrowing by businesses and households. This borrowing, in turn, is used to finance new investment, which in turn stimulates economic growth and eventually inflation in the macroeconomy.

A seminal article on the bank lending channel of monetary policy transmission is Anil Kashyap and Jeremy Stein's (2000) study, which found support for the existence of the bank lending channel in an analysis of quarterly balance sheet data on U.S. commercial banks from 1976 to 1993. Kaoru Hosono (2006) builds on the model proposed by Kashyap and Stein (2000), extending their empirical analysis to include not only liquidity, but also bank capital, in an analysis of the transmission of Japanese monetary policy during the period 1975 to 1999. Echoing some of the findings of Kashyap and Stein (2000), Hosono (2006) finds evidence of a bank lending channel in Japan, and concludes that it works more effectively through smaller, less liquid, banks with higher capital ratios. In sub-sample analysis however, Hosono (2006) demonstrates that the effectiveness of the bank lending channel of monetary policy transmission is asymmetric: during period of monetary tightening, bank liquidity plays an important role in transmission, while during periods of monetary policy tightening, bank capital becomes paramount.

The study most closely related to our study, however, is that of David Bowman et al. (2015) which examines the impact of unconventional monetary policy in Japan. Bowman et al. (2015) empirically evaluate the effect of Japan's first pioneering experiment with quantitative easing policy from 2001 to 2006 (QE1) on bank lending. They find a positive, statistically significant impact of bank liquidity on bank lending during the period of QE1 but conclude that it is so small as to be quantitatively, economically, rather insignificant. 
The rest of this study is organized as follows. The next section discusses the data used in the analysis and the empirical methodology, after which the empirical results are presented and discussed. The final section concludes.

\section{Data and Methodology}

\section{Data}

We use an unbalanced panel of data on 147 Japanese banks' balance sheets and financial statements over the 15-year period between 2000 and 2015 from the Japanese Bankers Association (JBA). The data frequency is semi-annual, as balance sheet and financial statement information is reported every September and March (note that Japan's fiscal year runs from April 1 to March 31). Thus, our panel of data includes a total of 4,003 bank-period observations. Table 1 reports the summary statistics.

Table 1. Summary Statistics, 2000-2015

\begin{tabular}{|l|c|c|c|c|}
\hline & Mean & $\begin{array}{c}\text { Standard } \\
\text { Deviation }\end{array}$ & Min & Max \\
\hline Variable Name & $0.85 \%$ & 5.24 & $-103.73 \%$ & $84.43 \%$ \\
\hline Liquidity Ratio (\%) & $6.64 \%$ & 3.91 & $1.13 \%$ & $54.85 \%$ \\
\hline Total Assets (log, million yen) & 14.67 & 1.23 & 10.38 & 19.12 \\
\hline Total Deposits (log, million yen) & 14.45 & 1.38 & 4.01 & 18.70 \\
\hline Equity Ratio (\%) & $5.04 \%$ & 4.93 & -78.82 & 79.83 \\
\hline Bad Loan Ratio (\%) & 81.79 & 95.55 & -612.47 & $1,916.83$ \\
\hline No. of Banks (i) & \multicolumn{5}{|c|}{147} \\
\hline No. of Time Periods (t) & \multicolumn{5}{|c|}{4,003} \\
\hline No. of Observations & \multicolumn{5}{|c}{} \\
\hline
\end{tabular}

Source: Japanese Bankers Association. 


\section{Empirical Methodology}

Our baseline estimation regresses the panel of data described above using the following reduced-form equation:

$$
\Delta \log \left(\mathrm{L}_{\mathrm{i}, \mathrm{t}+1}\right)=\beta_{0}+\beta_{1} \mathrm{LR}_{\mathrm{i}, \mathrm{t}}+\mathrm{BX}_{\mathrm{i}, \mathrm{t}}+\varepsilon_{\mathrm{i}, \mathrm{t}+1}
$$

where:

$\Delta \log \left(\mathrm{L}_{\mathrm{i}, \mathrm{t}+1}\right)$ represents log change of loans for bank $\mathrm{i}$ at time $\mathrm{t}+1$

$\mathrm{LR}_{\mathrm{i}, \mathrm{t}}$ represents the liquidity ratio of bank $\mathrm{i}$ at time $\mathrm{t}$, defined as the ratio of liquid assets ("cash and due from banks" plus "call loans") divided by total assets

$\mathrm{X}_{\mathrm{i}, \mathrm{t}}$ represents a vector of control variables, including the log of total assets, the log of total deposits, the equity ratio (the ratio of bank equity to total assets) and the bad loan ratio (the ratio of bad loans to total bank equity; bad loans are defined as the sum of "loan to borrowers in legal bankruptcy," "past due loans in arrears by six months or more," "loans in arrears by three months or more and less than six months" and "restructured loans") for bank $i$ at time $t$

$\varepsilon_{\mathrm{i}, \mathrm{t}+1}$ : represents the error term for bank $\mathrm{i}$ at time $(\mathrm{t}+1)$

In equation 1 , the main parameter of interest is $\beta_{1}$, the coefficient on the liquidity ratio. If monetary policy is effective, the estimate of $\beta_{1}$ will be positive and statistically significant, indicating that a higher bank liquidity ratio leads to higher bank loan growth.

The empirical methodology used starts with a simple pooled ordinary least squares (OLS) regression, then turns to balanced panel data analysis, exploring the effect of including both individual and time fixed effects. Finally, to address concerns about lagged dependent variable bias, we report the results of generalized method of moments analysis (GMM). 


\section{Empirical Results}

Table 2. The Effect of Higher Bank Liquidity Ratios on Loan Growth

Dependent Variable: Loan Growth $\Delta \log (\mathrm{L})_{\mathrm{i}, \mathrm{t}+1}$

\begin{tabular}{|c|c|c|c|c|c|}
\hline & $\begin{array}{c}\text { Pooled } \\
\text { Ordinary } \\
\text { Least } \\
\text { Squares } \\
\text { (OLS) }\end{array}$ & \begin{tabular}{|c|} 
Panel \\
Analysis \\
with Indi- \\
vidual \\
Fixed Ef- \\
fects \\
\end{tabular} & $\begin{array}{c}\text { Panel } \\
\text { Analysis } \\
\text { with Time } \\
\text { Fixed Ef- } \\
\text { fects }\end{array}$ & $\begin{array}{c}\text { Two } \\
\text { Step } \\
\text { System } \\
\text { GMM }\end{array}$ & $\begin{array}{c}\text { Two Step } \\
\text { Difference } \\
\text { GMM }\end{array}$ \\
\hline Independent Variables & (1) & (2) & (3) & (4) & (5) \\
\hline Constant Term & $\begin{array}{l}-0.00 \\
(0.01)\end{array}$ & & & & \\
\hline Liquidity Ratio, $\mathrm{LR}_{\mathrm{i}, \mathrm{t}}$ & $\begin{array}{c}0.06 * * \\
(0.03)\end{array}$ & $\begin{array}{c}0.14^{* * *} \\
(0.03)\end{array}$ & $\begin{array}{c}0.06 * * * \\
(0.03)\end{array}$ & $\begin{array}{c}0.15^{* *} \\
(0.08)\end{array}$ & $\begin{array}{c}0.19 \\
(0.12)\end{array}$ \\
\hline Log Total Assets & $\begin{array}{c}0.00 \\
(0.00)\end{array}$ & $\begin{array}{c}-0.05^{* * *} \\
(0.01)\end{array}$ & $\begin{array}{c}0.00 \\
(0.00)\end{array}$ & $\begin{array}{c}0.00 \\
(0.00)\end{array}$ & $\begin{array}{l}-0.06 \\
(0.06)\end{array}$ \\
\hline Equity Ratio, $\mathrm{ER}_{\mathrm{i}, \mathrm{t}}$ & $\begin{array}{c}0.08 \\
(0.06)\end{array}$ & $\begin{array}{c}0.53^{* * *} \\
(0.10)\end{array}$ & $\begin{array}{c}0.06 \\
(0.06)\end{array}$ & $\begin{array}{c}0.04 \\
(0.20)\end{array}$ & $\begin{array}{l}1.23 * * \\
(0.50)\end{array}$ \\
\hline Bad Loan Ratio & $\begin{array}{c}-0.01 * * * \\
(0.00)\end{array}$ & $\begin{array}{c}-0.01^{* * *} \\
(0.00)\end{array}$ & $\begin{array}{c}-0.00 * * * \\
(0.00)\end{array}$ & $\begin{array}{l}-0.00 \\
(0.00)\end{array}$ & $\begin{array}{l}-0.01 \\
(0.01)\end{array}$ \\
\hline No. Obs. & 2,580 & 2,460 & 2,460 & 4,003 & 2,172 \\
\hline
\end{tabular}

Note: Standard errors are written in parenthesis below the finding, and asterisks represent significant findings at the $10 \% *, 5 \% * *$, and $1 \% * * *$ level, respectively. $I=147$ (or 133 ), $\mathrm{T}=30$ (or 33), $\mathrm{N}=4,003$ (or 2,460)

The results reported in Table 2, which reports the results of empirical estimation of equation (1), indicate that monetary policy was effective during the period of our study. For nearly all empirical methodologies-pooled OLS, panel data with individual fixed effects or time fixed effects, and for GMM-the coefficient estimate of interest is positive and highly statistically significant at the $5 \%$ or even $1 \%$ level. This suggests that banks with relatively higher liquidity ratios in a given period tend to have statistically significantly higher loan growth in the following period.

The size of the parameter estimate nearly doubles when individual bank fixed effects are accounted for in column (2), and when we address 
the possibility of endogeneity due to a lagged dependent variable on the right-hand side through two-step system GMM analysis.

\section{Conclusions}

The empirical results presented above indicate that unconventional monetary policy has significant effects through the bank lending channel, although the impact on bank lending is quantitatively small. This raises questions as to the appropriateness of the policy implementation and the long-term implications of the policy for the banking sector and macroeconomy as a whole. In particular, further investigation is needed regarding potential differences in the impact of QE across banking institutions and potential unintended side effects of QE.

\section{References}

Bowman, David, Fang Cai, Sally Davies, and Steven Kamin, S. 2015. Quantitative Easing and Bank Lending: Evidence from Japan. Journal of International Money and Finance (57): 15-30.

Hosono, Kaoru. 2006. "The Transmission Mechanism of Monetary Policy in Japan: Evidence from 30 Banks' Balance Sheets." Journal of the Japanese and International Economies 20 (3): 380-405.

Kashyap, Anil. and Jeremy Stein. 2000. "What Do a Million Observations on Banks Say About the Transmission of Monetary Policy?" American Economic Review 90 (3): 407-428. 